\title{
Publication Guidelines for Collaborators
}

I. According to the type of contribution

- Unpublished articles (up to 30 standard pages of 30 lines with 70 characters each, or approximately 60,000 characters, including notes and references).

- Bibliographic essays (up to 12 standard pages of 30 lines with 70 characters each, or 25,200 characters, including notes and references) critical reviews of one book only or of several books on related issues.

- Literature reviews (up to 6 standard pages of 30 lines with 70 characters each, or 6,300 characters) - short reviews of recent books.

2. Regarding the review for publication

- The journal publishes articles in Portuguese, English, and Spanish, accepting submissions in French, whose publication is dependent on the possibility of translation.

- Original articles, essays and reviews submitted to the journal are first read by the editors. If the submitted material is considered to be in accordance with the editorial policy and fulfills the essential academic requirements, it will be forwarded for evaluation by at least two experts in the field, ensuring the anonymity of both the authors and reviewers.

- In the evaluation, the peer reviewers should take into account the content, relevance and quality of the contributions, considering writing, text originality, quality of argument and literature, relevance and appropriateness of the methodology employed. The evaluation result can be one of the following: a) accept; b) accept with minor revisions; c) revise and resubmit; d) refuse. In case of a positive and a negative review, the work is to be submitted to a third 
reviewer. When there is a need for changes relating to aspects of grammar, spelling and normative nature only, in order to maintain the homogeneity of the publication, the editors reserve the right to make any necessary changes, complying with the author's style.

3. Every article must be accompanied by an abstract containing between 100 and 150 words, with a version in Portuguese and English, with three to five keywords. Authors should send their professional information (institution, position, title, most important publications), mailing address and e-mail. This information should appear on a separate page that also contains the title of the article.

4. Footnotes should be indicated by Arabic numerals in ascending order at the end of each page and should contain relevant information, and may not consist of simple bibliographic references.

5. Citations and references should appear in the body of the text with the following formatting:

- (author's last name, year of publication, page) according to the example: (WAGLEY, 1977, p. 160-162).

6. The references, in alphabetical order, must be at the end of the work and follow the format that appears in the following examples (please observe punctuation, spaces, bold type and capitalization as follows):

- Book:

VEBLEN, T. A teoria da classe ociosa. São Paulo: Livraria Pioneira, 1965.

- Collection:

LIPSET, S. M. (org.). Política e Ciências Sociais. Rio de Janeiro: Zahar, 1972.

- Article from a collection:

WALLERSTEIN, I. Three Ideologies or One? The Pseudo-Battle of Modernity. In: TURNER, S. P. (org.). Social Theory \& Sociology. The Classics and Beyond. Oxford: Blackwell, 1996.

- Article from a journal:

PAIXÃO, A. L. A teoria geral da ação e a arte da controvérsia. Revista Brasileira de Ciências Sociais, São Paulo, v. 4, n. 11, p. 34-56, out.1989. 
- Academic thesis or dissertation:

MIGUEL, S. M. Um olhar para dentro: o movimento feminista no Rio de Janeiro. Florianópolis. Dissertation (MA in Political Sociology). Universidade Federal de Santa Catarina, 1988.

7. Graphs, figures, tables, charts or maps should be inserted in the body of the text, properly numbered and captioned and with their respective references. They must be provided in a format that allows their direct reproduction.

8. Upon publication of the article or bibliographic essay, the author will receive three copies of the journal. For reviews, the author will receive two copies.

9. Bibliographical essays and reviews must provide complete references about the works reviewed, indicating the number of pages of each.

10. The submission of any collaboration implies the full transfer of copyrights to the journal Política e Sociedade. A new publication of the same text, whether by the initiative of the author or third parties, must indicate that it was previously published in this journal, citing the edition and date of publication. There is no guarantee that the original submissions will be returned.

I I. The opinions expressed in signed articles are solely the responsibility of their authors.

12. Authors should send their texts preferably through the journal's website (http://www.periodicos.ufsc.br/index.php/politica) or in electronic format (Microsoft Word, OpenOffice or RTF, provided the file does not exceed $2 \mathrm{MB}$ ) to the address ps@cfh.ufsc.br.

\section{For more information, please contact the Graduate Program in Political Sociology:}

Phone: +554837219253

Fax: +554837219098

E-mail Address: ppgsp@cfh.ufsc.br

Web: http://www.sociologia.ufsc.br 


\section{Conditions for Submission}

As part of the submission process, authors are required to confirm their submission's compliance with all of the following items. Submissions may be returned to authors that do not adhere to these guidelines.

I. The contribution is assumed to be original and unpublished, and that it is not being evaluated for publication by another journal. If this is not the case, a justification should be provided under the "Comments to the Editor" section.

2. The submission files are in Microsoft Word, OpenOffice or RTF format (provided they do not exceed $2 \mathrm{MB}$ )

3. All Web page addresses (URLs) included in the text (e.g. http://www. ibict.br) are active and clickable.

4. The text is single-spaced; font is size 12 ; italics are used instead of underlining (except for URL addresses); figures and tables are included in the text, not at the end.

5. The text adheres to the stylistic and bibliographic requirements outlined in the Publication Guidelines for collaborators.

6. The identification of authorship of this work was removed from the file and from the Properties option in Microsoft Word, thus ensuring the journal's confidentiality criterion. 